\title{
23. COMPRESSIONAL DEFORMATION OF OCEANIC LITHOSPHERE IN THE CENTRAL INDIAN OCEAN: WHY IT IS WHERE IT IS 1,2
}

\author{
Garry D. Karner, ${ }^{3}$ and Jeffrey K. Weissel ${ }^{3}$
}

\begin{abstract}
The prominent example of compression of oceanic lithosphere in the central Indian Ocean south of India and Sri Lanka does not occur where recent models for the state of stress in the Indo-Australian Plate predict maximum horizontal compressive stress. The Afanasiy-Nikitin seamount group, which erupted in Late Cretaceous or early Tertiary time, is centrally located in the region where deformation is best developed. We suggest that critical wavelength components in the deflection caused by the emplacement of these seamounts were preferentially amplified when north-south directed compression was applied to the northern part of the Indo-Australian Plate in the late Miocene. To test this hypothesis, we develop a simple two-dimensional model for compression of a thin elastic plate overlying an inviscid fluid, where the plate contains a pre-existing deflection. The deflection caused by seamount loading is obtained by approximating the topography of the Afanasiy-Nikitin Seamounts as a bi-variate Gaussian distribution. The $\leq 2-\mathrm{km}$ peak-to-trough amplitude and $200-\mathrm{km}$ average wavelength characteristics of the broad-scale crustal deformation and the observed east-west-trending pattern of free-air gravity anomalies are best matched in the modeling with an applied horixontal compression between $1.5-2.0 \times 10^{13} \mathrm{~N} / \mathrm{m}$, a plate with an effective elastic thickness of $10-15 \mathrm{~km}$ at the time of compression and $5 \mathrm{~km}$ at the time of seamount emplacement. Furthermore, infilling of topographic lows of the deformation by Bengal Fan sediment rather than seawater is a major factor in promoting lithospheric deformation by horizontal compression.
\end{abstract}

\section{INTRODUCTION}

The manner in which the lithosphere responds to applied loads (or forces, $\Delta \mathrm{F}$ in Fig. 1) fundamentally defines its isostatic state. Therefore, a prime goal in studying the isostatic or flexural response of the lithosphere is to gain insight into its mechanical properties. The lithosphere can be loaded in three general ways (Fig. 1): (1) Loading by lateral or in-plane forces, the subject of this paper, (2) loading from above, such as seamount emplacement or delta progradation, and/or (3) loading from below, such as by the dynamic or thermal effects of small-scale mantle convection. The purpose of this paper is to investigate the mechanical behavior of the central Indian Ocean lithosphere when subjected to large in-plane compression.

Regional deformation of oceanic lithosphere by horizontal compression is more clearly expressed in the central Indian Ocean south of India than in any other region of the world's seafloor. The area affected, which spans approximately the latitude band $5^{\circ} \mathrm{N}$ to $10^{\circ} \mathrm{S}$ between the Chagos-Laccadive Ridge and the Ninetyeast Ridge (Fig. 2), is remote from the conventionally-defined boundaries of the Indo-Australian Plate. The main geophysical characteristics of the deformed area can be summarized as follows:

1. The oceanic crust and most of the overlying Bengal Fan sediments are deformed into broad, east-west-trending undulations with wavelengths $100-300 \mathrm{~km}$ and amplitudes up to 2 km (Fig. 3, Weissel et al., 1980; Geller et al., 1983; Neprochnov et al., 1988). Turbidites derived from erosion of the Himalayas have progressively infilled topographic lows of

\footnotetext{
${ }^{1}$ Cochran, J. R., Stow, D.A.V., et al., 1990. Proc. ODP, Sci. Results, 116: College Station, TX (Ocean Drilling Program).

2 Lamont-Doherty Geological Observatory Contribution No. 4630.

3 Lamont-Doherty Geological Observatory of Columbia University, Palisades, NY 10964-0190, U.S.A.
}

these broad undulations (Fig. 3). As can be seen in Cochran, Stow, et al. (1989), this infill is also characterized by numerous unconformities that also represent sequence boundaries (using the terminology of Vail (1987). This is compelling evidence for a deformation that is a function of time.

2. Large-amplitude, east-west-trending gravity (Fig. 4) and geoid anomalies are associated with the broad basement deformation features (Weissel and Haxby, 1982, 1984; McAdoo and Sandwell, 1985).

3. The surface of oceanic crust and overlying sediments are broken into fault blocks (Fig. 3) bounded by high-angle reverse faults spaced $5-20 \mathrm{~km}$ apart, indicating north-south shortening in the crust (Eittreim and Ewing, 1972; Weissel et al., 1980; Geller et al., 1983; Neprochnov et al., 1988). The dip of the faulted sediment increases with depth, suggesting that these faults are in fact growth faults.

4. An unusually high number of earthquakes have occurred in the region. The larger events, which were mainly located in the lithospheric mantle, reflect continuing displacement on thrust and strike-slip faults in response to northsouth directed compression (Fig. 5; Stover, 1966; Sykes, 1970; Stein and Okal, 1978; Bergman and Solomon, 1980, 1985; Wiens and Stein, 1983; Wiens, 1986; Petroy and Wiens, 1989). In addition, the Chagos-Laccadive Ridge tends to be associated with large normal-fault earthquakes, consistent with the predictions of Cloetingh and Wortel $(1985,1986)$.

5. Heat-flow measurements in the deformed region exhibit many abnormally high values (Anderson et al, 1977; Weissel et al., 1980; Geller et al., 1983; Stein and Weissel, in press; Forsyth et al., unpubl. data). Some of the high values are associated with nonlinear (convex up) temperature-depth profiles, indicative of upward fluid flow.

6. Drilling at Sites 717-719 (Fig. 1) during ODP Leg 116 (Cochran, Stow, et al., 1989) confirmed earlier suggestions that the deformation began in the late Miocene.

These observations delineate a broad area of oceanic lithosphere in the central Indian Ocean that has been de- 
1. LATERAL FORCES

MODEL:

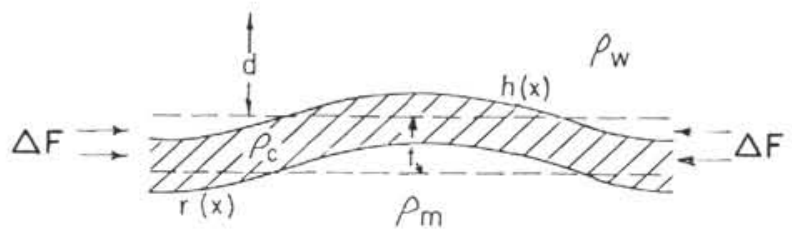

EXAMPLE:

INTRAPLATE DEFORMATION

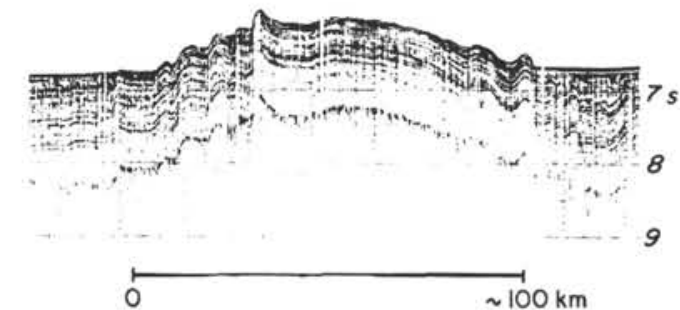

2. SURFACE FORCES

MODEL:

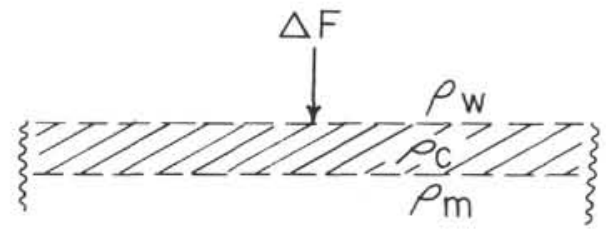

EXAMPLE:

SEAMOUNT OR RIDGE

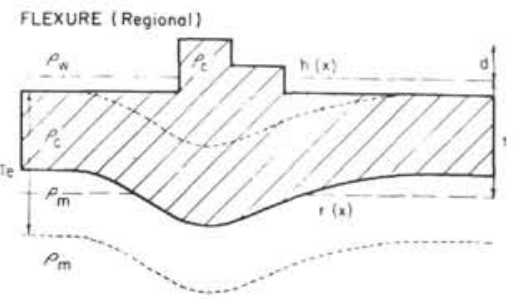

3. BOUYANCY FORCES

MODEL:

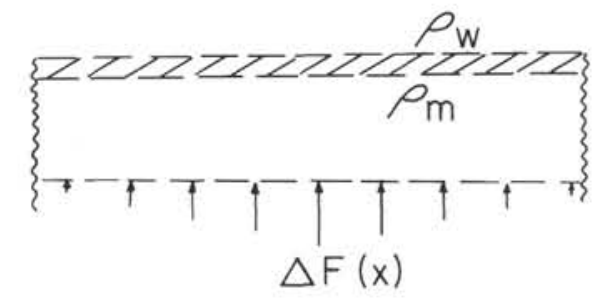

EXAMPLE:

SUBLITHOSPHERIC CONVECTION

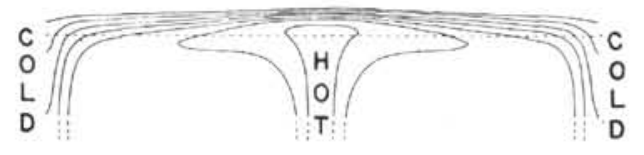

Figure 1. Geological loads and their lithospheric flexural (isostatic) responses: (1) Lateral loads, (2) surface loads, and (3) sublithospheric loads. 


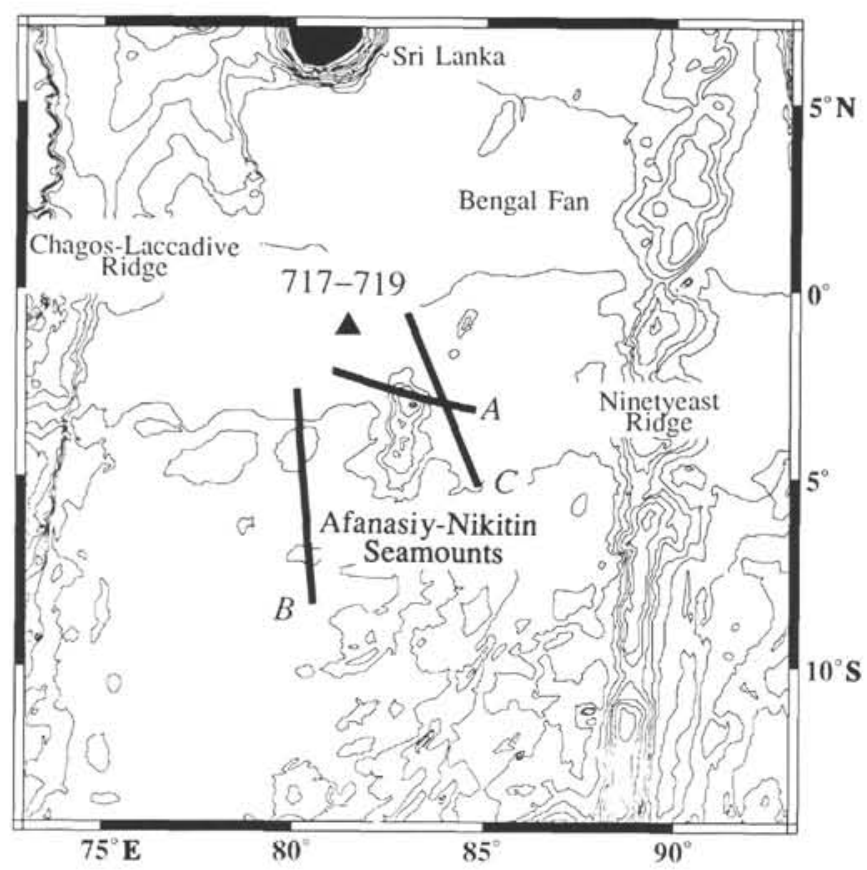

Figure 2. General bathymetry of the central Indian Ocean showing the major bathymetric features discussed in the text. The AfanasiyNikitin Seamounts are highlighted using the $3500-\mathrm{m}$ isobath. The central Indian Ocean deformation zone primarily exists between the Chagos-Laccadive and Ninetyeast Ridges, centered on the AfanasiyNikitin Seamounts. The southernmost extent of Bengal Fan turbidites is given approximately by the east-west-trending $5000-\mathrm{m}$ isobath. The black triangle represents the location of ODP Leg (Sites 717-719). Heavy black lines locate the seismic sections shown in Figure 3.

formed under predominantly north-south compression during the last several millions of years.

Additional but indirect evidence for north-south lithospheric shortening comes from studies of relative plate motion data (spreading rates and transform fault azimuths) from the spreading systems of the Indian Ocean. Minster and Jordan (1978) found that allowing about $10 \mathrm{~mm} / \mathrm{yr}$ of northwestsoutheast convergence between an "Indian" and an "Australian" Plate along the northern Ninetyeast Ridge better satisfies observed spreading rates and directions than does the conventional concept of an integral Indo-Australian Plate. More refined analyses of plate motion data subsequently led to the definition of a "diffuse" boundary between the Indian and Australian plates extending across the equatorial region of the Indian Ocean between the Central Indian Ridge and the Sumatran Trench (Wiens et al., 1985; Gordon et al., in press). The center of rotation for the putative Indian and Australian Plates as determined by Wiens et al. (1985) lies at $1.5^{\circ} \mathrm{S}$, $69.6^{\circ} \mathrm{E}$, and the calculated rotation rate predicts north-south lithospheric shortening along $85^{\circ} \mathrm{E}$ longitude in the deformed region at a rate $>10 \mathrm{~mm} / \mathrm{yr}$ (Wiens et al., 1985). In contrast, Gordon et al. (in press) using a larger plate-motion data set but in addition, allowing motion between the Indian and Arabian plates, predicted a rate of north-south shortening along $85^{\circ} \mathrm{E}$ of $4 \pm 3 \mathrm{~mm} / \mathrm{yr}$.

Weissel et al. (1980) explored the possibility that the broad undulations of the oceanic crust in the central Indian Ocean represent buckling of the oceanic lithosphere. They found that the $160-\mathrm{km}$ wavelength undulation characteristic of the deformation could be modeled as buckling of an elastic plate of thickness $T_{e} \approx 12 \mathrm{~km}$ under a stress of $\approx 2.4 \mathrm{GPa}$ ( $\left.24 \mathrm{kbar}\right)$, which is equivalent to a compressive force per unit length of $\approx 3 \times 10^{13} \mathrm{~N} / \mathrm{m}$. The high value for the critical buckling stress casts doubt on elastic plate buckling as an explanation for the compressional deformation in the central Indian Ocean. Our current understanding from laboratory experiments on rock strength is that rocks comprising the lithosphere cannot support such high levels of compressive stress (e.g., Kirby, 1983). We conclude, therefore, that these undulations do not represent buckling of the lithosphere. Weissel et al. (1980) did note, however, that the magnitude of compression must be high enough to (a) account for the widespread faulting in the upper part of the oceanic lithosphere, and (b) reduce the effective elastic thickness $T_{e}$ of the lithosphere by a factor $\approx 2$ compared to values $20-30 \mathrm{~km}$ obtained from flexure of Late Cretaceous to early Tertiary oceanic lithosphere beneath seamounts and at trenches (Watts et al., 1980; Bodine et al., 1981).

More elaborate lithospheric rheologies have been explored to overcome objections to the high stresses required under elastic buckling theory. McAdoo and Sandwell (1985) used arguments based on yield-stress envelopes, which describe the depth-dependence of strength in the lithosphere (Brace and Kohlstedt, 1980; Goetze and Evans, 1979) to explain how plastic yielding in the upper and lower parts of the lithosphere reduces the effective elastic thickness, $T_{e}$, of the lithosphere as the level of compression is increased. While the force/unit length required to buckle the plate with the observed average wavelength remains as calculated by Weissel et al. (1980), the average compressive stress in the lithosphere is much less, essentially because the critical buckling load is applied to a plate thicker than $T_{e}$. Zuber (1987) developed dynamic models for the compression of a viscous half-space in which the lithosphere is represented as a strong layer overlying a weaker substratum. If the strength contrast between the lithosphere and the substrate is large, the lithosphere folds with a wavelength similar to that found for the elastic buckling case. In contrast, if the lithosphere is relatively weak, thickening occurs beneath topographic highs of the deformation (Zuber, 1987).

While the studies of Zuber (1987) and McAdoo and Sandwell (1985) show that more elaborate rheologies permit buckling-like behavior with depth-averaged stress levels lower than for a purely elastic plate, one essential property of the observed deformation in the central Indian Ocean remains unanswered. Why does it occur where it does? This question is particularity important because models for the present state of stress in the Indo-Australian Plate (Cloetingh and Wortel, $1985,1986)$ predict that horizontal compressive stress should be largest in the lithosphere adjacent to the Sumatran and Andaman sections of the Indonesian trench system (Fig. 5). Why then, is compressional deformation more pronounced in lithosphere west of the Ninetyeast Ridge where the level of compression is predicted to be less (Fig. 5)?

The main goal of this paper is to answer that question. Weissel et al., (1980; their Fig. 5) demonstrated from the available seismic reflection data that the Afanasiy-Nikitin seamount group is centrally located with respect to the broad-scale basement structures defining the deformation zone in the central Indian Ocean. The free-air gravity anomaly over the Afanasiy-Nikitin seamount region supports this assertion (Fig. 4), although the gravity field is complicated by other bathymetric features, primarily north-northeast fracture-zone trends through the region (e.g., the $86^{\circ}$ fracture zone). An important question is the age of emplacement of the Afanasiy-Nikitin Seamounts relative to the timing of turbidite deposition. As can be seen in the single-channel seismic section in Figure 6, the entire sedimentary section onlaps the northwestern margin of the Afanasiy-Nikitin Seamounts. Seismic stratigraphic correlation from Sites $717-719$ to the loca- 
A

\section{Afanasiy-Nikitin}

\section{Seamounts}

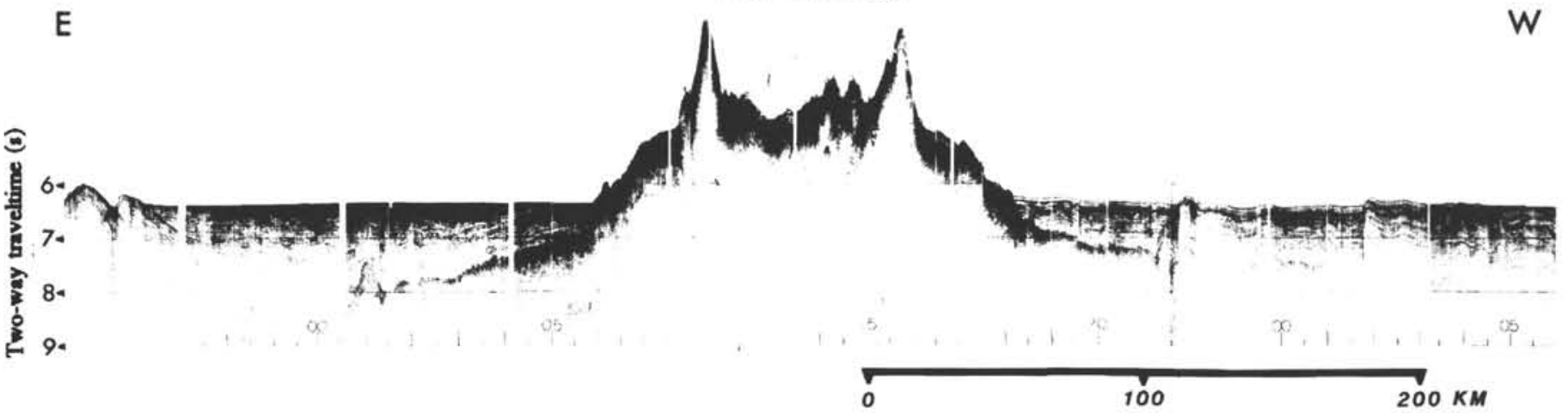

B

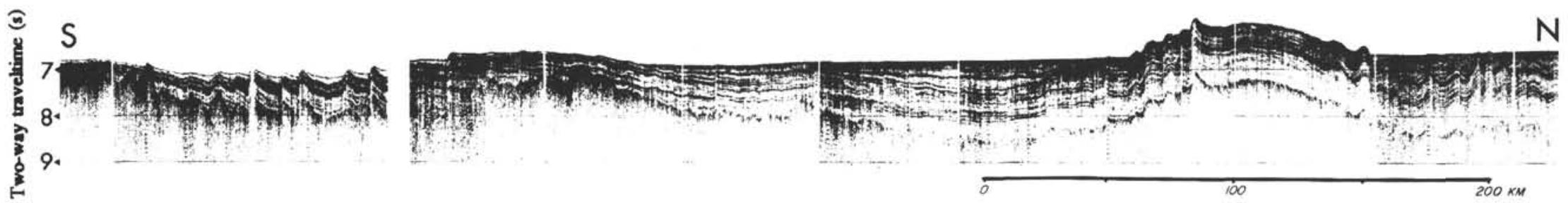

C
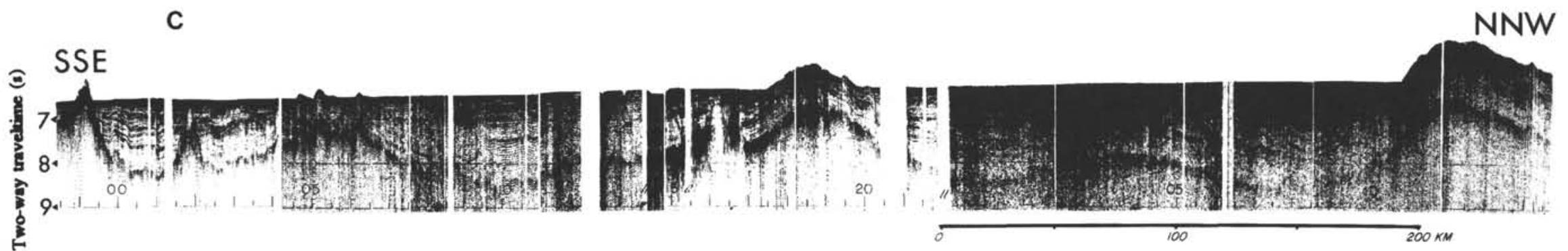

Figure 3. Single-channel, seismic reflection profiles across the central Indian Ocean deformation zone. Locations shown in Figure 2. Profile (A) shows the general east-west form of the Afanasiy-Nikitin Seamounts. Profiles $(\mathbf{B})$ and $(\mathbf{C})$ clearly indicate the long wavelength $(\approx 200 \mathrm{~km})$ and amplitude $(2$-s twt $)$ of the deformation zone. Bengal Fan turbidites can be seen draping the deformation zone. As seen in (B), the southern limit of the deformation zone approximately coincides with the distal edge of the fan sediments. 

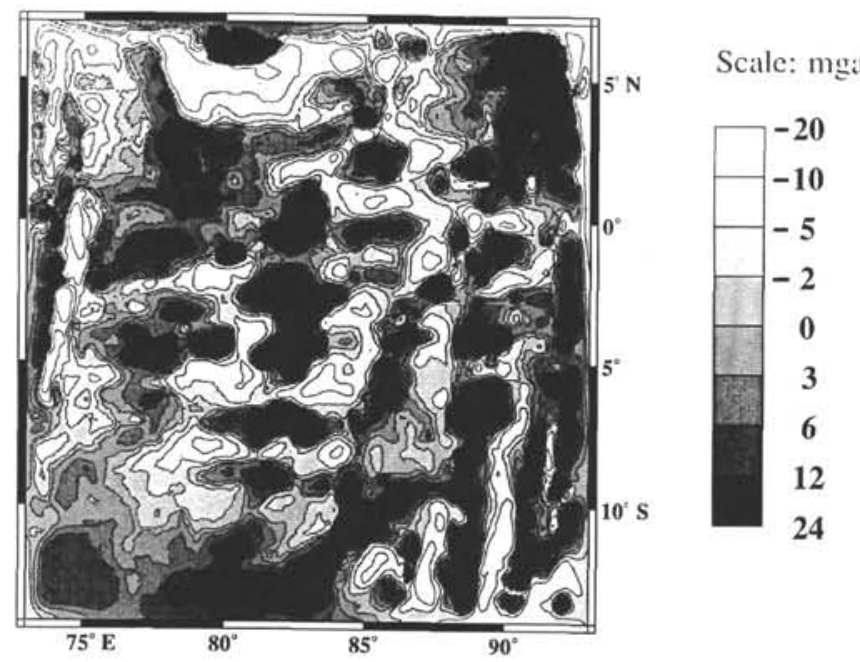

Figure 4. SEASAT-derived free-air gravity anomalies of the central Indian Ocean region. A nonlinear gray-scale was employed to emphasize the positive-negative "ripples" that characterize the gravity pattern over the Afanasiy-Nikitin Seamounts. The dark tones highlight positive free-air gravity anomalies while the lighter tones highlight regions of negative free-air gravity anomalies.

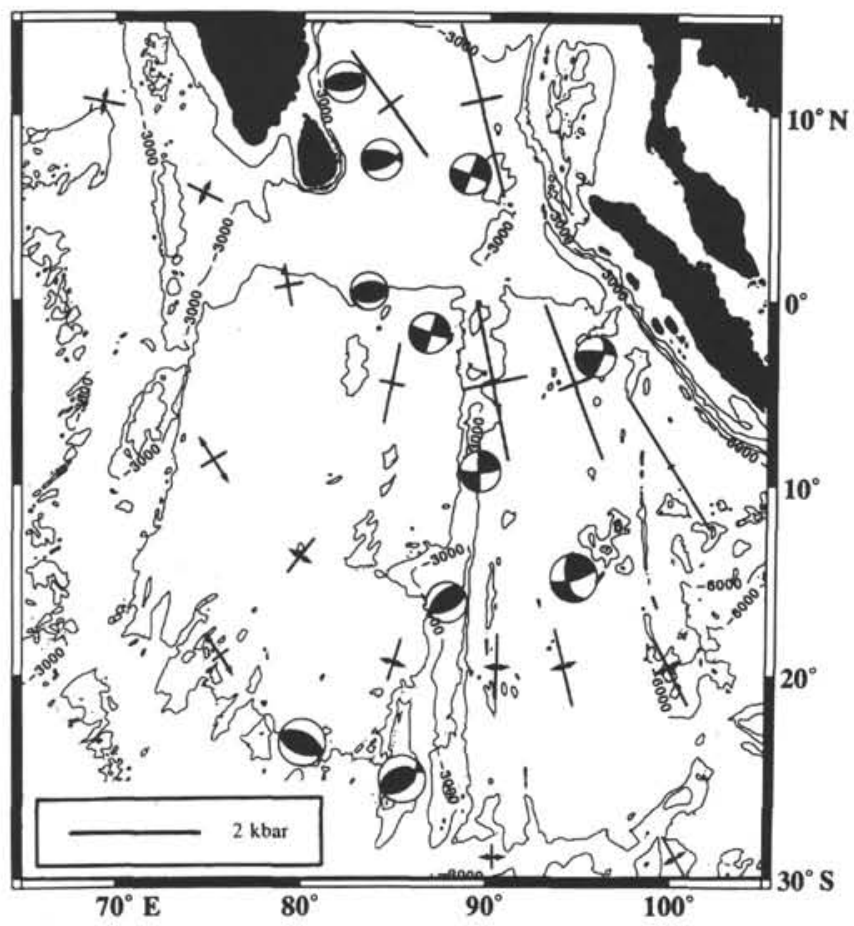

Figure 5. Intraplate seismicity (Bergman and Solomon, 1985) and predicted stress levels (Cloetingh and Wortel, 1985, 1986) for the central Indian Ocean. The seismicity, either the result of strike-slip or thrust-faulting in the oceanic mantle, indicates a north-south-directed compression. The predicted level of in-plane force is of the order of $2-4 \times 10^{13} \mathrm{~N} / \mathrm{m}$ based on the balance of forces engendered in the Indo-Australian Plate, primarily by slab pull and ridge push (Cloetingh and Wortel, 1985 1986). Gravity modeling suggests a maximum in-plane force of $2 \times 10^{13} \mathrm{~N} / \mathrm{m}$. "Beach-ball" symbols indicate the position of intraplate earthquakes and their first-motion solutions, thereby defining the contemporary state-of-stress in the Indo-Australian Plate.

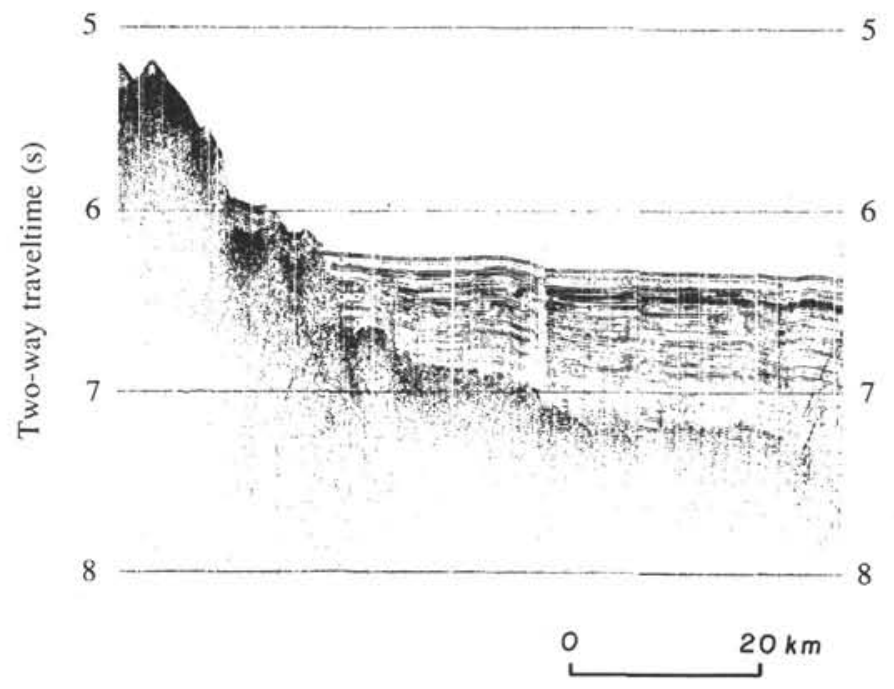

Figure 6. Seismic reflection detail across the northeastern edge of the Afanasiy-Nikitin Seamounts showing the onlapping relationship between the sediments and oceanic basement/seamounts. Seismic stratigraphic correlation from Sites 717-719 indicates that the majority of the onlapping section is predeformational. Therefore, the seamounts pre-date the sedimentary section.

tion of the seamounts indicates that most of the onlapping section is predeformational. Further, there is no evidence in the seismic reflection data for a disruption of the sediment due to igneous intrusion, thereby suggesting that the seamounts did not form as a recent magmatic event. Thus, the emplacement of these seamounts must have occurred prior to the onset of intraplate compression. The crust onto which the seamounts built is 74-80 Ma (Campanian; Peirce, Weissel et al., 1989), based on correlatable seafloor-spreading magnetic anomalies. Because biostratigraphic ages obtained from chalk intercalated with dredged basalts from the Afanasiy-Nikitin Seamounts are Late Cretaceous (R. A. Scrutton, pers. comm., 1989), it would appear that these seamounts were emplaced in close proximity to the ridge axis.

We suggest that, since the late Miocene, horizontal compression has amplified selected wavelength components in the earlier lithospheric deformation caused by seamount loading. We first present the theoretical background for calculating the additional deflection due to application of a horizontal load to an elastic plate containing an initial deflection. The total deformation obtained from the modeling and its gravity effect are compared with the observations from the central Indian Ocean. We determine the magnitude of compressive force/ unit length and elastic plate thickness which best match the amplitudes and wavelengths of the deformation and its free-air gravity anomaly.

Note that our discussion is always in terms of in-plane forces, not in terms of in-plane stress (cf., Cloetingh et al., 1985). We do this because stress depends on the thickness of lithosphere to which the in-plane force is applied. We take this thickness to be equal to the effective elastic thickness of the lithosphere, which is a function of the age of the lithosphere at the time of loading.

\section{COMPRESSIONAL DEFORMATION OF AN ELASTIC PLATE CONTAINING A PRE-EXISTING DEFLECTION}

Deformation under horizontal load occurs more easily for a plate containing an initial deflection of appropriate wavelength characteristics compared to a flat plate to which a critical 
buckling load must be applied (Lambeck, 1983a and b). We suggest that the emplacement of the Afanasiy-Nikitin Seamounts in the Late Cretaceous provided the required earlier deflection in the case of the central Indian Ocean. Moreover, we will show that infilling of the deformation by Bengal Fan sediment plays an important role in facilitating the deformation, a result previously obtained by Zuber (1987) in her analysis of the growth of an initial instability in a layered viscous continuum.

Two sets of flexural rigidities and infill densities are required in the modeling: Those applicable at the time of seamount emplacement, which we will designate by the super/ subscript $i$, and those at the time of in-plane force application, which we will designate by the super/subscript $f$. That is, $T_{e}{ }^{i}$ is the effective elastic thickness of the lithosphere at time of seamount emplacement (equivalent flexural rigidity, $D_{i}$ ); $T_{e}^{f}$ is the effective elastic thickness at time of in-plane force application (equivalent flexural rigidity, $D_{f}$ ); $\rho_{2}^{i}$ represents the infill density $\rho_{\text {infill }}$ at the time of seamount emplacement; and $\rho_{2}^{f}$ the infill density at the time of in-plane force application. The effective elastic thickness, $T_{e}$, is related to plate rigidity by

$$
D=E T_{e}^{3 / 12\left(1-v^{2}\right)}
$$

where $E$ is Young's modulus, and $v$ is Poisson's ratio.

In terms of the geological history of the central Indian Ocean basin, two factors appear important in understanding the late Miocene and younger compressional deformation of the lithosphere. First, when the Afanasiy-Nikitin Seamounts were emplaced, the flexural "moat" surrounding the seamounts was essentially sediment free (Fig. 7; Karner and Weissel, in press). Second, since deformation began, Bengal
Fan sedimentation has been sufficient to at least partially cover the deforming lithosphere (Fig. 7). Drilling at Sites 717-719 shows, in fact, that fan turbidite deposition occurred at the latitude of the deformed region as early as the early Miocene, well before compression began (Cochran, Stow, et al., 1989). As pointed out by Karner and Weissel (in press) and seen in Figure 3, the effect of sediment infilling is important. The progressive decrease of the deformation amplitude south of the Afanasiy-Nikitin Seamounts directly correlates with the thinning of Bengal Fan turbidites.

\section{TWO-DIMENSIONAL PLATE FLEXURE AND ASSOCIATED GRAVITY EFFECTS}

To determine the lithospheric deformation caused by both two-dimensional vertical loads and directionally applied horizontal forces, we solve the partial differential equation governing the deformation $w_{1}(x, y)$ of an elastic plate containing an initial deflection $w_{o}(x, y)$ by applied vertical loads and in-plane forces (Timoshenko and Woinowsky-Prieger, 1959):

$$
D\left[\frac{\partial^{4} w_{1}}{\partial x^{4}}+2 \frac{\partial^{4} w_{1}}{\partial x^{2} \partial y^{2}}+\frac{\partial^{4} w_{1}}{\partial y^{4}}\right]+\Delta \rho_{2} g w_{1}
$$

$$
+N_{\mathrm{x}} \frac{\partial^{2}}{\partial x^{2}}\left(w_{o}+w_{1}\right)+N_{\mathrm{y}} \frac{\partial^{2}}{\partial y^{2}}\left(w_{o}+w_{1}\right)=\Delta \rho_{1} g(x, y)
$$

where $x$ and $y$ are cartesian coordinates corresponding to the east-west and north-south directions, respectively, and represent the principal stress directions, $N_{x}$ is the in-plane force per unit length applied in the east-west direction and $N_{y}$ is the
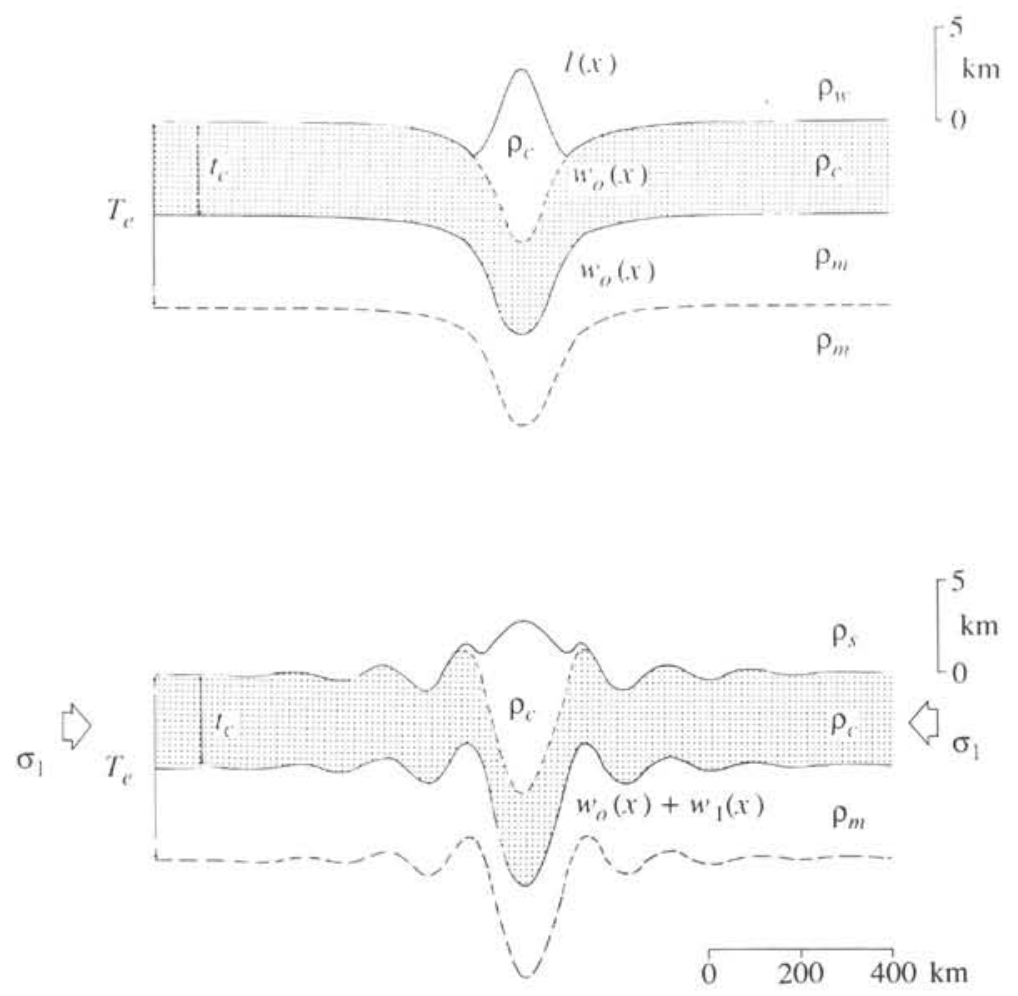

Figure 7. Schematic summarizing the variables used in the modeling and the form of the lithospheric deformation induced by: (1) The initial seamount load, and (2) the application of in-plane compression. Note that the principal stress, $\sigma_{1}$, implies an in-plane compressive force of $T_{e} \cdot \sigma_{1}$ where $T_{e}$ is the effective elastic thickness of the lithosphere at the time of force application. 
in-plane force per unit length applied in the north-south direction. Further, we will assume that horizontal shearing forces (i.e., $N_{x y}$ and $N_{y x}$ ) are unimportant. Figure 7 summarizes the variables used in the modeling and schematically shows the form of the lithospheric deformation induced by: (1) The initial seamount load, and (2) the consequent application of in-plane compression.

It is convenient to express the solution to (2) in the Fourier domain such that:

$$
\begin{gathered}
W_{1}(u, v)= \\
\frac{\Delta \rho_{1} g L(u, v)}{\left[\left(D u^{4}-N_{x} u^{2}\right)+\left(D v^{4}-N_{y} v^{2}\right)+2 D u^{2} v^{2}+\Delta \rho_{2} g\right]} \\
+\frac{\left(N_{x} u^{2}+N_{y} v^{2}\right) W_{o}(u, v)}{\left.\left[D u^{4}-N_{x} u^{2}\right)+\left(D v^{4}-N_{y} v^{2}\right)+2 D u^{2} v^{2}+\Delta \rho_{2} g\right]}
\end{gathered}
$$

where $(u, v)$ are the wavenumbers corresponding to the $x$ and $y$ coordinates, respectively. We will set $L(u, v)=0$ to investigate the response of the lithosphere to variations in $N_{x}$ and $N_{y}$. From (3), the additional deflection $W_{1}(u, v)$ due only to horizontal compression is therefore:

$$
\begin{gathered}
W_{1}(u, v)= \\
\frac{\left(N_{x} u^{2}+N_{y} v^{2}\right) W_{0}(u, v)}{\left[\left(D u^{4}-N_{x} u^{2}\right)+\left(D v^{4}-N_{y} v^{2}\right)+2 D u^{2} v^{2}+\Delta \rho_{2} g\right]}
\end{gathered}
$$

In the case of the deformation in the central Indian Ocean, we assume that the initial deflection $W_{o}(u, v)$ is produced by emplacement of the Afanasiy-Nikitin Seamounts, which can be represented as a two-dimensional surface load $h(x, y)$, giving:

$$
W_{o}(u, v)=\frac{\Delta \rho_{1}}{\Delta \rho_{2}^{i}}\left[1+\frac{D_{i}\left(u^{2}+v_{2}\right)^{2}}{\Delta \rho_{2}^{i} g}\right]^{-1} H(u, v)
$$

The total deformation $W_{t}(u, v)$ is simply the sum $\left(W_{o}+W_{1}\right)$ :

$$
W_{t}(u, v)=\frac{\Delta \rho_{1}}{\Delta \rho_{2}^{i}} \Phi(u, v) H(u, v)
$$

where $\Phi(u, v)$ is a linear admittance function describing the relation between the original seamount load $H(u, v)$ and the total deformation $W_{t}(u, v)$ :

$$
\begin{gathered}
\Phi(u, v)=\left[1+\frac{D_{i}\left(u^{2}+v^{2}\right)^{2}}{\Delta \rho_{2}^{i} g}\right]^{-1} . \\
{\left[1+\frac{D_{f}\left(u^{2}+v^{2}\right)^{2}-\left(N_{x} u^{2}+N_{y} v^{2}\right)}{\Delta \rho_{2}^{f} g}\right]^{-1} .} \\
{\left[1+\frac{D_{f}\left(u^{2}+v^{2}\right)^{2}}{\Delta \rho_{2}^{f} g}\right] .}
\end{gathered}
$$

For mathematical convenience, we represent the topography $\mathrm{h}(x, y)$ of the Afanasiy-Nikitin Seamounts by a bi-variate normal distribution:

$$
h(x, y)=\frac{h_{o}}{2 \pi \sigma_{x} \sigma_{y}} e^{-x^{2} / 2 \sigma_{x}} e^{-y^{2} / 2 \sigma_{y}}
$$

where $h_{o}$ is the maximum height of the seamounts (measured from the top of oceanic crust, as opposed to the present-day seafloor), and $\sigma_{x}$ and $\sigma_{y}$ define dimensions of the seamount in the east-west and north-south directions respectively. We assumed values of 40 and $90 \mathrm{~km}$ for $\sigma_{x}$ and $\sigma_{y}$, and $4 \mathrm{~km}$ for $h_{o}$ (cf., Figs. 3 and 6).

Once the admittance function $\Phi$, representing the relationship between original seamount load and final deformation, has been calculated, it is possible to calculate the associated free-air gravity effect of the original seamount load and deformation, plus the gravity effect of the additional deformation induced by the application of an in-plane force. The resulting gravity effect arises from three major sources:

1. The water-seamount interface, which can be expressed as: $\Delta g_{1}=2 \pi \gamma e^{-k d} \Delta \rho_{1} H(u, v)$, where $d$ is the unperturbed basement depth, $\Delta \rho_{1}=\rho_{\text {load }}-\rho_{2}{ }^{i}$, and $\gamma$ is Newton's gravitational constant;

2. the sediment-basement interface, expressed as: $\Delta g_{2}=$ $-2 \pi \gamma e^{-k d}\left(\rho_{c}-\rho_{2}^{f}\right) W_{t}(u, v)$; and

3. the crust-mantle interface, expressed as: $\Delta g_{3}=-2 \pi \gamma$ $e^{-k\left(d+t_{c}\right)}\left(\rho_{m}-\rho_{c}\right) W_{t}(u, v)$, where $t_{c}$ is the crustal thickness (assumed to be $5 \mathrm{~km}$ ).

The total free-air gravity effect $\Delta g_{\text {total }}(u, v)$ is given by the sum of these three contributions,

$$
\begin{gathered}
\Delta g_{\text {total }}=2 \pi \gamma e^{-k d} \Delta \rho_{1} \\
{\left[1-\frac{\left(\rho_{c}-\rho_{2}^{f}\right)}{\Delta \rho_{2}^{i}} \Phi-\frac{\left(\rho_{m}-\rho_{c}\right)}{\Delta \rho_{2}^{i}} \Phi e^{-k t_{c}}\right] H(u, v)}
\end{gathered}
$$

where $\Phi$ is given by (7). Although (9) is a linear approximation to the total gravity effect of the seamounts, it incorporates the complete solution for the deformation induced by in-plane force variations. This is important in our study because it is the amplitude of the free-air gravity anomalies over the regions adjacent to the Afanasiy-Nikitin Seamounts that ultimately can be used to determine the level of in-plane force. This is possible because free-air gravity anomalies are caused by lateral variations in the distribution of mass (or density) and imply departures from hydrostatic equilibrium. In turn, departures from hydrostatic equilibrium must be supported by nonhydrostatic forces. In the case of the central Indian Ocean, this nonhydrostatic force is the applied in-plane compression.

\section{APPLICATION TO THE DEFORMED REGION}

We now apply the above theory to calculate the twodimensional deflection and free-air gravity effect, (1) at the time of emplacement of the Afanasiy-Nikitin Seamounts early in the history of the central Indian Ocean (Figs. 7 and 8a), and (2) following application of north-south horizontal compression at about $7 \mathrm{Ma}$ (Figs. 7 and $8 \mathrm{~b}$ ). Contour intervals for the deflection and gravity maps are $100 \mathrm{~m}$ and $10 \mathrm{mgals}$, respectively. The high density of contouring in Figure 8 is primarily 
intended for graphic display of the two-dimensional pattern, rather than to show the actual magnitude of the modeled deflection and free-air gravity.

As expected from the simple Gaussian shape assumed for the seamount topography in (8), the surface (and Moho) deflection and resulting free-air gravity effect display smooth elliptical contour patterns (Fig. 8a). Following Karner and Weissel (in press), we assumed that the effective elastic thickness $T_{e}^{i}$ of the lithosphere at the time of seamount loading was $5 \mathrm{~km}$, and that the infill density $\rho_{2}^{i}$ was $1.03 \mathrm{~g} / \mathrm{cm}^{3}$. The low $T_{e}^{i}$ is based on the empirical relationship between $T_{e}$ and lithospheric age derived by Bodine et al., (1981). As stated above, the age of the seamounts is Late Cretaceous, similar to the age of the underlying oceanic crust according to seafloor spreading magnetic lineations (e.g. Liu et al., 1983). Along a northsouth profile through the center of mass of the seamount, the deflection due to seamount loading ranges from $-2600 \mathrm{~m}$ directly under the seamount to $+30 \mathrm{~m}$ at the flexural bulge (Fig. 9). Similarly, the free-air gravity anomaly ranges from +32 mgals to -17 mgals. Except for a change in deflection width, an east-west profile through the center of mass of the seamount has the same deflection range (Fig. 9).
A

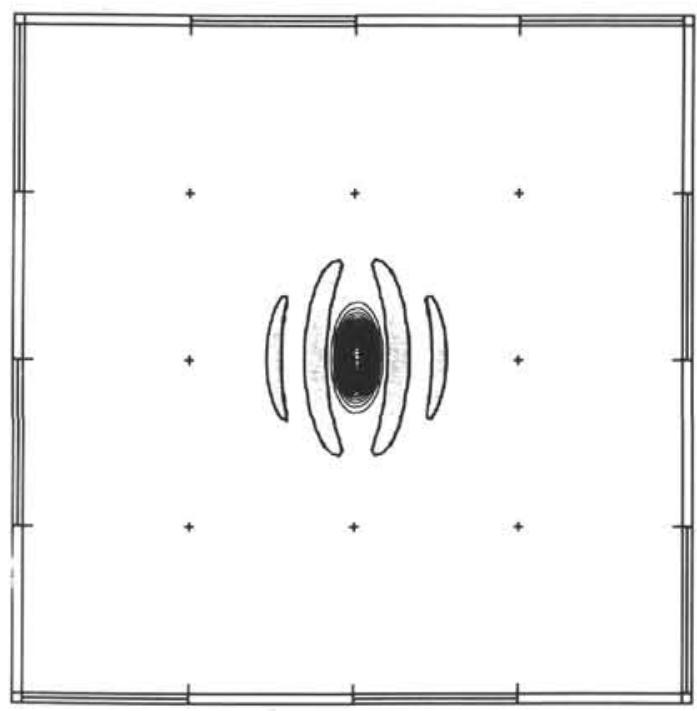

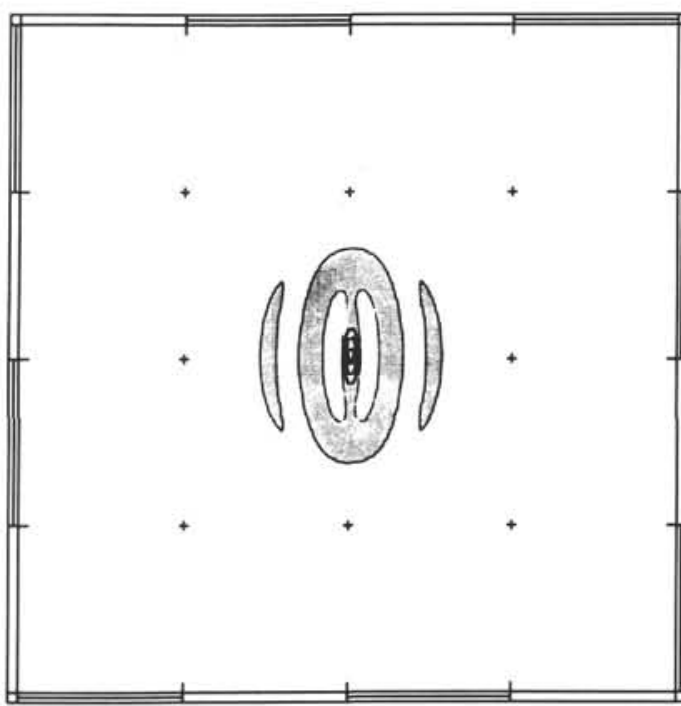

2000

1500
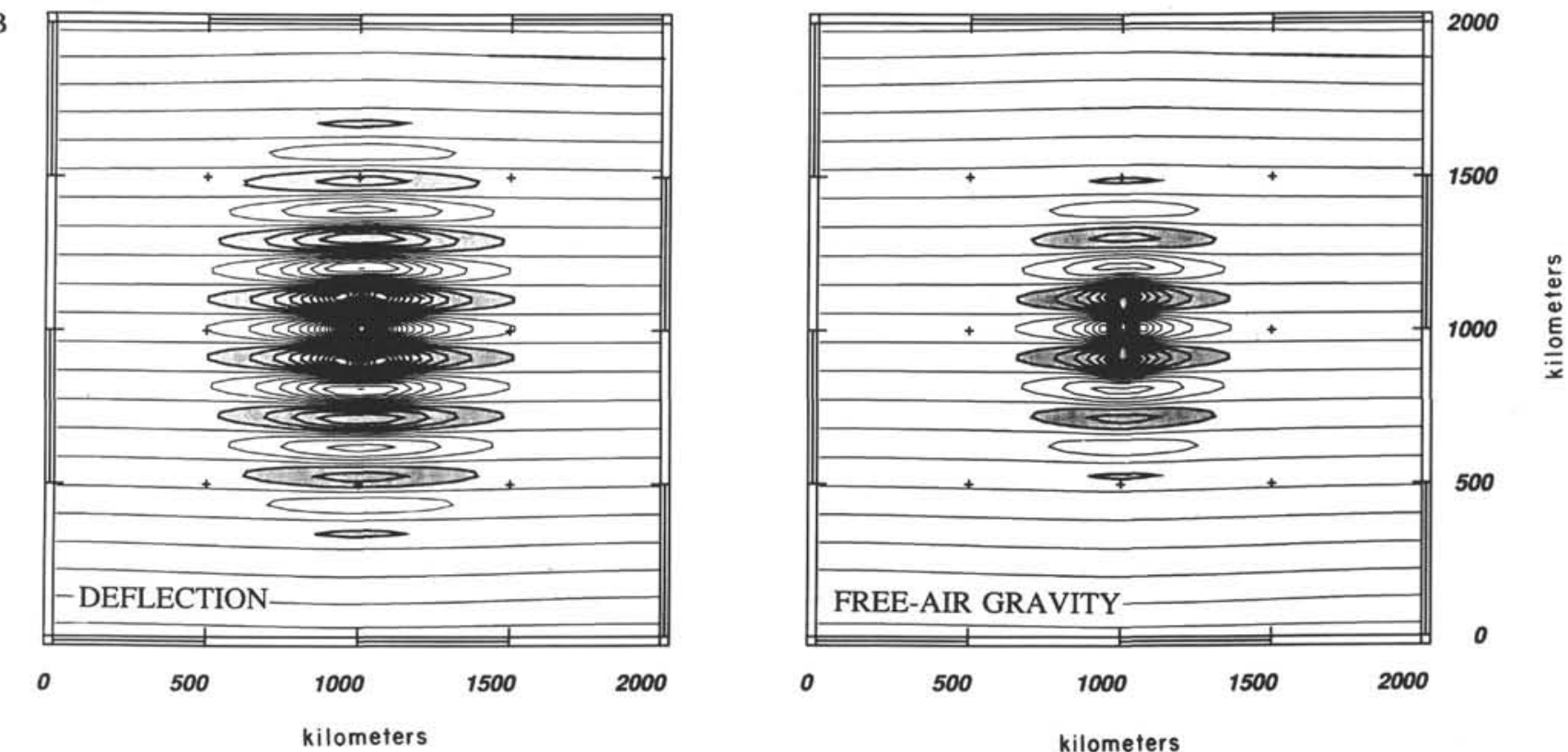

Figure 8. Theoretical deformation of a thin elastic plate containing a pre-existing deflection A. before and B. after the application of a north-south in-plane compressive force. The original form of the topographic load is assumed gaussian and is assumed representative of the Afanasiy-Nikitin Seamounts. The free-air gravity effect A. before and B. after compression is also shown. Before compression, the free-air gravity effect consists of a sequence of concentric ellipses. After compression, in contrast, the gravity is dominated by a set of positive-negative "ripples" distributed symmetrically north and south of the Afanasiy-Nikitin Seamounts. The general elliptical pattern and rippled shape of the predicted free-air gravity effect over the deformation zone is strikingly similar to the observed free-air gravity anomaly (Fig. 4). 
The application of north-south-directed horizontal compression produces dramatic changes in the deflection and free-air gravity patterns (Figs. 8 b and 9). The total deflection and gravity patterns in Figure $8 \mathrm{~b}$ were obtained by applying a force/unit length $N_{y}=2.0 \times 10^{13} \mathrm{~N} / \mathrm{m}$ in the north-southdirection and a force/unit length $N_{x}=0$ in the east-west direction. The amplitude of the applied force/unit length is tightly constrained in that slightly increasing this force above $2.0 \times 10^{13} \mathrm{~N} / \mathrm{m}$ results in extreme and unacceptable plate deformations. However, acceptable fits to the observed gravity are obtained for an applied force/unit length range of $1.5-2.0 \times 10^{13} \mathrm{~N} / \mathrm{m}$. The effective elastic thickness $T_{e}^{f}$ of the lithosphere at the time of in-plane compression uniquely determines the deformation wavelength. To match the observed $\approx 200-\mathrm{km}$ deformation wavelength implies a $T_{e}^{f}$ of $\approx 10$ $\mathrm{km}$. Sediments, with constant density $\rho_{2}^{f}$ of $2.2 \mathrm{gm} / \mathrm{cm}^{3}$, were allowed to infill the deformation caused by compression.

Shortening of the plate in the north-south direction implies extension in the east-west direction (by Poisson's ratio), thus explaining the east-west "ripples" seen in the deflection and free-air gravity patterns (Figs. $8 \mathrm{~b}$ and 9 ). The total or resultant deflection ranges from $-4660 \mathrm{~m}$ beneath the center of mass of the seamount to $+1090 \mathrm{~m}$ at the first positive ripple at either end of the seamount group (Fig. 9). As can be seen in Figures $8 \mathrm{~b}$ and 9 , the amplitudes of the ripples decrease north and south away from the seamounts.

The calculated pattern of gravity anomalies associated with the deformation (Figs. 8 b and 10) is qualitatively similar to the map of gravity anomalies obtained from SEASAT and GEOSAT altimetry Figs. 4 and 10). The general elliptical gravity pattern centered on the Afanasiy-Nikitin Seamounts, the

\section{NORTH-SOUTH PROFILE}
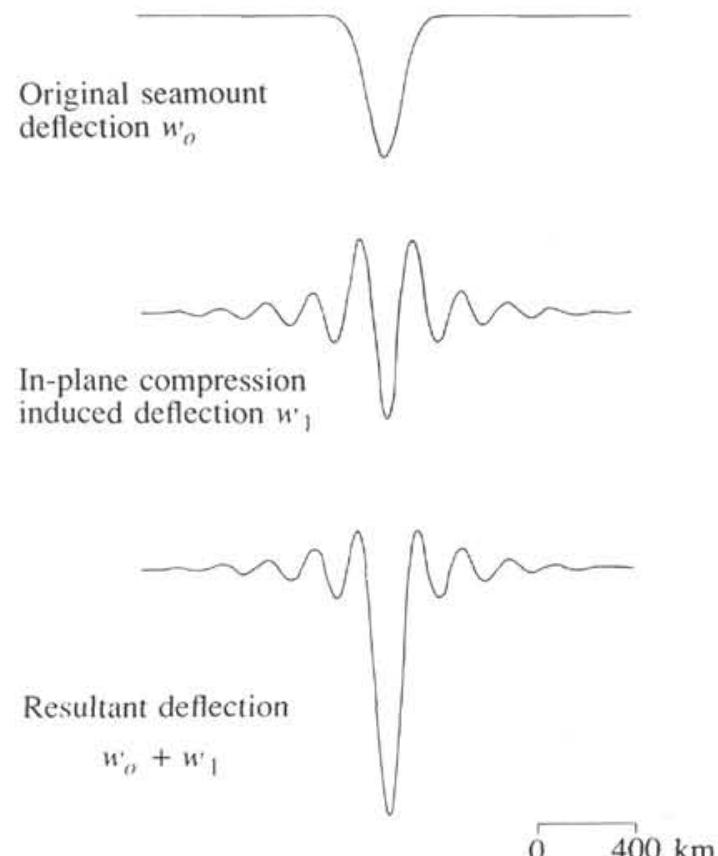

number of east-west-trending ripples, their characteristic 200$\mathrm{km}$ wavelength, and the way ripple amplitude decreases north and south of the Afanasiy-Nikitin Seamounts, are similar in the observed and calculated gravity anomalies. The calculated free-air gravity effect ranges from +120 mgals to -65 mgals along an east-west profile across the seamounts. The amplitudes of the calculated positive ripples vary from 5 to 20 mgals with the negative ripples varying from -5 to $-30 \mathrm{mgals}$. The largest positive ripples occur over the northern and southern ends of the Afanasiy-Nikitin Seamounts (Figs. 4, 8, and 10), which is deformed into an hour-glass planform by the compression. Note that the regular spacing of the deformation in the central Indian Ocean is principally controlled by the flexural rigidity of the lithosphere at the time of in-plane compression (Karner and Weissel, in press) Consequently, it is not necessary that the load be distributed periodically to produce the observed pattern of deformation (cf., Zuber, 1987).

Our estimated level of force using the free-air gravity anomaly, $1.5-2.0 \times 10^{13} \mathrm{~N} / \mathrm{m}$, is in excellent agreement with force estimates obtained by other workers using different methods. For example, Cloetingh and Wortel (1986) obtained a maximum force/unit length of 3.0-5.0 $\times 10^{13} \mathrm{~N} / \mathrm{m}$ by modeling the distribution and magnitude of in-plane force within the Indo-Australian Plate subject to forces at its boundaries and along its base. In contrast, McAdoo and Sandwell (1985) determined a maximum force/unit length of $2.76 \times 10^{13}$ $\mathrm{N} / \mathrm{m}$ by determining the buckling load for a yield-stress envelope representation of the central Indian Ocean lithosphere. For Zuber's (1987) preferred modes of viscous lithospheric deformation, the applied force/unit-length was $6.0 \times$

\section{EAST-WEST PROFILE}
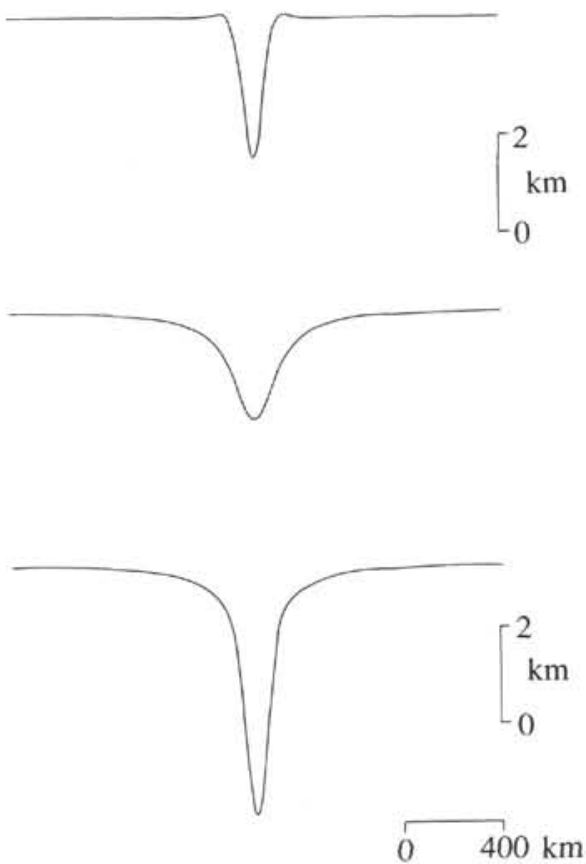

Figure 9. Comparison between the form of the modeled lithospheric deformation in a north-south and east-west section across the center of mass of the Afanasiy-Nikitin Seamounts. $w_{o}$ represents the deflection of the lithosphere associated with the original emplacement of the seamounts. The application of an in-plane compressive force induces an additional deformation, $w_{1}$. The total or resultant deformation of the lithosphere is therefore $w_{o}$ $+w_{1}$. Note that compression in the north-south direction creates tension in the east-west direction. This shortening/extension relationship is reflected in the form of the respective plate deformations. 

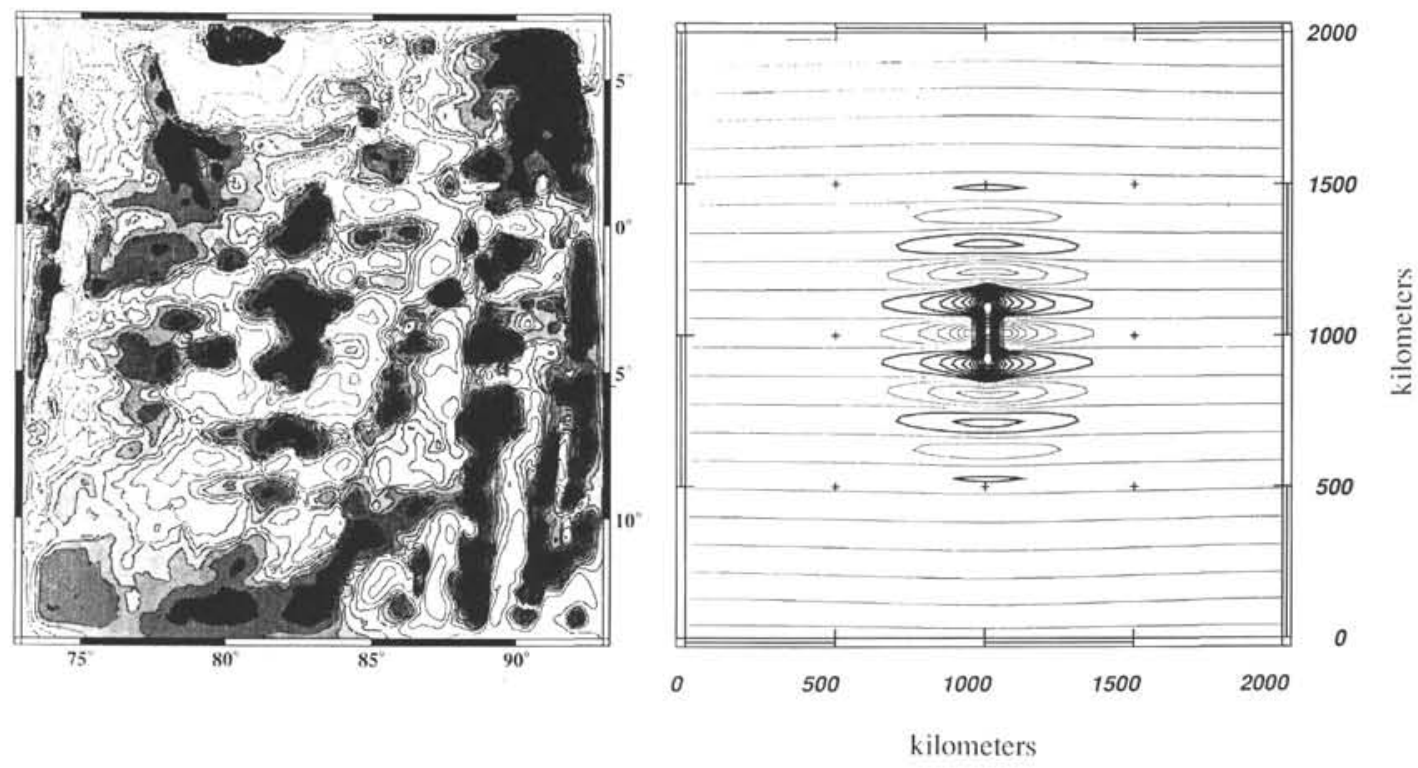

Figure 10. Comparison between the predicted and observed free-air gravity anomaly in the central Indian Ocean. The gray-scale is the same as in Figure 4. Note the hour-glass planform pattern of the positive gravity anomaly over the Afanasiy-Nikitin Seamounts and the characteristic $200-\mathrm{km}$ deformation wavelength.

$10^{12}-3.2 \times 10^{13} \mathrm{~N} / \mathrm{m}$. While all these force estimates may seem extreme, they are of the same order-of-magnitude. This force level of $10^{13} \mathrm{~N} / \mathrm{m}$ is likely a direct consequence of the extreme tectonic setting represented by the attempted subduction of the Indian and Australian continental lithospheres whereas oceanic subduction has continued along the Java and Sumatran trenches between the collision zones.

Gravity anomalies associated with the Ninetyeast and Chagos-Laccadive Ridges, which are not included in the modeling, can be seen as north-south-trending features to the east and west of the Afanasiy-Nikitin Seamounts and the deformation zone in Figure 2. North-south-trending features such as the Ninetyeast and Chagos-Laccadive Ridges are expected to be affected less by a north-south-directed force because they effectively have an infinite wavelength in that direction. While the northern Ninetyeast Ridge appears to be segmented, reflection seismic data confirm that there is no geographic connection between the Afanasiy-Nikitin deformation zone and this segmentation. Given the relative simplicity of our modeling approach, the similarities between the observed and predicted oceanic crust deformation and gravity anomalies in the central Indian Ocean are remarkably good.

As stated earlier, the Afanasiy-Nikitin seamount group is centrally located in that region of the central Indian Ocean where the deformation is best developed. Our analysis, therefore, does not preclude compression-related, but discrete, deformation zones in other regions of the Indo-Australian Plate as suggested, for example, by Stein et al. (1989) for the northeast-southwest bathymetric lineations observed east of the Ninetyeast Ridge. Our analysis does suggest, however, that these other compression-related features should have nucleated about pre-existing lithospheric deformations. For the deformational features east of the Ninetyeast Ridge (Stein et al., 1989), we suggest that relatively old seamounts such as the Cocos-Keeling seamount group and deflections related to thermal contraction or differential thermal stresses across fracture zones might provide the required deformation nucleus.

\section{CONCLUSIONS}

We have developed and analyzed a simple two-dimensional model for the deformation by horizontal compression of an elastic plate containing a pre-existing deflection to explain why the prominent example of compressionally-deformed oceanic lithosphere in the central Indian Ocean basin is not located where levels of compressive stress in the IndoAustralian Plate are predicted to reach maximum values (Cloetingh and Wortel, 1985, 1986). We conclude from the modeling results that:

1. The location of the deformed region is controlled by an earlier lithospheric deformation that we attribute to emplacement of the Afanasiy-Nikitin Seamount group in Late Cretaceous or early Tertiary time. North-south-directed compression, which began in the late Miocene, amplified suitable wavelength components in the earlier deflection. As stated earlier, the Afanasiy-Nikitin seamount group is centrally located in the region where deformation is best developed. Our analysis, therefore, does not preclude compression-related deformation in other regions of the Indo-Australian Plate as suggested, for example, by Stein et al. (in press) for the northeast-southwest bathymetric lineations observed east of the Ninetyeast Ridge. Our analysis does suggest, however, that these other features should have nucleated about preexisting lithospheric deformations. For the deformation features east of the Ninetyeast Ridge (Stein et al., in press), we suggest that the Cocos-Keeling seamount group and deflections related to thermal contraction or differential thermal stresses across fracture zones might provide the required earlier deformations.

2. Observed amplitudes and wavelengths of oceanic crust deformation and free-air gravity anomalies are best matched 
in the modeling using an applied horizontal compression between 1.5 and $2.0 \times 10^{13} \mathrm{~N} / \mathrm{m}$, a plate with an effective elastic thickness $T_{e}^{f}$ of $10-15 \mathrm{~km}$ at the time of compression and an effective elastic thickness $T_{e}^{i}$ of $5 \mathrm{~km}$ at the time of original seamount emplacement. The infill material at the time of compression was assumed to be Bengal Fan sediments with a density of $2.2 \mathrm{~g} / \mathrm{cm}^{3}$ while during the initial seamount emplacement, the infill was assumed to be seawater of density $1.03 \mathrm{~g} / \mathrm{cm}^{3}$.

3. The application of a horizontal force has apparently reduced the effective elastic thickness of the lithosphere by a factor of two compared to values $20-30 \mathrm{~km}$ obtained from studies of lithospheric flexure beneath seamounts and at trenches (Watts et al., 1980; Bodine et al., 1981). Following Weissel at al. (1980), McAdoo and Sandwell (1985), and Karner and Weissel (in press), the anomalously low $T_{e}^{f}$ determined for the lithosphere of the central Indian Ocean appears related to plastic yielding at the top and bottom of the lithosphere in response to horizontal loading.

\section{ACKNOWLEDGMENTS}

Marcus Langseth, Anthony Watts, David McAdoo, Carol Stein, and Neal Driscoll critically reviewed the manuscript, and their comments are appreciated. Major support for this work was provided by U.S. National Science Foundation grant OCE $85-11980$ to JKW.

\section{REFERENCES}

Anderson, R. N., Langseth, M. G., and Sclater, J. G., 1977. Mechanisms of heat transfer through the floor of the Indian Ocean. $J$. Geophys. Res., 82:3391-3409.

Bergman, E. A., and Solomon, S. C., 1980. Oceanic intraplate earthquakes: implications for local and regional intraplate stress. $J$. Geophys. Res., 85:5389-5410.

1985. Earthquake source mechanisms from bodywaveform inversion and intraplate tectonics in the northern Indian Ocean. Phys. Earth Planet. Inter., 4:1-23.

Bodine, J. H., Steckler, M. S., and Watts, A. B., 1981. Observations of flexure and the rheology of the oceanic lithosphere. J. Geophys. Res., 86:3695-3707.

Brace, W. F., and Kohlstedt, D. L., 1980. Limits on lithospheric stress imposed by laboratory experiments. J. Geophys. Res. 85:6248-6252.

Cloetingh, S., and Wortel, R., 1985. Regional stress field of the Indian Plate. Geophys. Res. Lett., 12:77-80.

1986. Stress in the Indo-Australian Plate. Tectonophysics, 132:49-67.

Cloetingh, S., McQueen, H., and Lambeck, K., 1985. On a tectonic mechanism for regional sealevel variations. Earth and Planet. Sci. Lett., 75:157-166.

Cochran, J. R., and Stow, D.A.V., et al., 1989. Proc. ODP, Init. Repts., 116: College Station, TX (Ocean Drilling Program).

DeMets, C., Gordon, R. G., and Argus, D. F., 1988. Intraplate deformation and closure of the Australian-Antarctica-Africa Plate circuit. J. Geophys. Res., 93:11,877-11,898.

Eittreim, S. K., and Ewing, J. I., 1972. Midplate tectonics in the Indian Ocean. J. Geophys. Res., 77:6413-6421.

Geller, C. A., Weissel, J. K., and Anderson, R. N., 1983. Heat transfer and intraplate deformation in the central Indian Ocean. $J$. Geophys. Res., 88:1018-1032.

Goetze, C., and Evans, B., 1979. Stress and temperature in the bending lithosphere as constrained by experimental rock mechanics. Geophys. J. R. Astron. Soc., 59:463-478.

Gordon, R. G., DeMets, C., and Argus, D. F., in press. Kinematic constraints on distributed lithospheric deformation in the equatorial Indian Ocean from present-day motion between the Australian and Indian plates. Tectonics.

Karner, G. D., and Weissel, J. K., in press. Factors controlling the location of compressional deformation of oceanic lithosphere in the central Indian Ocean. J. Geophys. Res.

Kirby, S. H., 1983. Rheology of the lithosphere. Rev. Geophys. 21:1458-1487.
Lambeck, K., 1983a. The role of compressive forces in intracratonic basin formation and mid-plate orogenies. Geophys. Res. Lett., 10:845-848.

1983b. Structure and evolution of the intracratonic basins of central Australia. Geophys. J. R. Astron., Soc., 74:843-886.

Liu, C. S., McDonald, J. M., and Curray, J. R., 1983. New constraints on the tectonic evolution of the eastern Indian Ocean. Earth Planet. Sci. Lett., 65:331-342.

McAdoo, D. C., and Sandwell, D. T., 1985. Folding of oceanic lithosphere. J. Geophys. Res., 90:8563-8568.

Minster, J. B., and Jordan, T. H., 1978. Present-day plate motions. J. Geophys. Res., 83:5331-5354.

Neprochnov, Y. P., Levchenko, O. V., Merklin, L. R., and Sedov, V. V., 1988. The structure and tectonics of the intraplate deformation area in the Indian Ocean. Tectonophysics, 156:89-106.

Peirce, J., Weissel, J., et al., 1989. Proc. ODP, Init. Repts., 121: College Station, TX (Ocean Drilling Program).

Petroy, D. E., and Wiens, D. A., 1989. Historical seismicity and implications for diffuse plate convergence in the northeast Indian Ocean. J. Geophys. Res., 94:12,301-12,321.

Stein, S., and Okal, E. A., 1978. Seismicity and tectonics of the Ninetyeast Ridge area: Evidence for internal deformation of the Indian Plate. J. Geophys. Res., 83:2233-2245.

Stein, C. A., Cloetingh, S., and Wortel, R., 1989. SEASAT gravity constraints on stress and deformation in the northeastern Indian Ocean. Geophys. Res. Lett., 16:823-826.

Stein, C. A., and Weissel, J. K., in press. Constraints on central Indian Basin thermal structure from heat flow, seismicity, and bathymetry. Tectonophysics.

Stover, C. W., 1966. Seismicity of the Indian Ocean. J. Geophys. Res., 71:2575-2581.

Sykes, L. R., 1970. Seismicity of the Indian Ocean and a possible nascent island arc between Ceylon and Australia. J. Geophys. Res., 75:5041-5055

Timoshenko, S. P., and Woinowsky-Prieger, S., 1959. Theory of plates and shells: New York, McGraw-Hill.

Vail, P. R., 1987. Seismic stratigraphy interpretation utilizing sequence stratigraphy. In Bally, A. W. (Ed.), Atlas of Seismic Stratigraphy. AAPG Stud. Geol. 27 (Pt. 1).

Warts, A. B., Bodine, J. H., and Steckler, M. S., 1980. Observations of flexure and the state of stress in the oceanic lithosphere. $J$. Geophys. Res., 85:6369-6376.

Weissel, J. K., Anderson, R. N., and Geller, C. A., 1980. Deformation of the Indo-Australian Plate. Nature, 287:284-291.

Weissel, J. K., and Geller, C. A., 1981. Preliminary results of the 1980 shipboard investigation of deformation of the Indo-Australian Plate, 1: Seismic reflection. Eos, 62:404.

Weissel, J. K., and Haxby, W. F., 1982. Predicting seafloor topography from SEASAT altimeter data using isostatic models. Eos, 63:907.

1984. A tectonic tour of the Indian Ocean via the SEASAT satellite. Eos, 65:185.

Wiens, D. A., and Stein, S., 1983. Age dependence of oceanic intraplate seismicity and implications for lithospheric evolution. $J$. Geophys. Res., 88:6455-6468.

Wiens, D. A., DeMets, C., Gordon, R. G., Stein, S., Argus, D., Engeln, J. F., Lundgren, P., Quible, D., Stein, C., Weinstein, S., and Woods, D. F., 1985. A diffuse plate boundary model for Indian Ocean tectonics. Geophys. Res. Lett., 12:429-432.

Wiens, D. A., 1986. Historical seismicity near Chagos: A complex deformation zone in the equatorial Indian Ocean. Earth Planet. Sci. Lett., 76:350-360.

Zuber, M. T., 1987. Compression of oceanic lithosphere: an analysis of intraplate deformation in the central Indian Basin. J. Geophys. Res., 92: 4817-4826.

Date of initial receipt: 28 June 1989

Date of acceptance: 6 February 1990 Ms 116B-154 